Recebido: 14/05/2018

Aprovado: 31/07/2018

\title{
"Discurso ou revólver"? "Tá na hora da revolução"? Diálogos anticoloniais e antirracistas entre o grupo de rap Facção Central, Achille Mbembe e Frantz Fanon
}

Matheus de Andrade Gomes*

Resumo: $O$ objetivo deste artigo é analisar as representações contidas no álbum $A$ marcha fúnebre prossegue, do grupo de rap paulista Facção Central, em debate com pensadores anticoloniais e antirracistas, como Achille Mbembe e Frantz Fanon, bem como seus pensamentos sobre a colonialidade e uma forma de produzir uma revolução nas realidades que afligem a população negra e pobre. Busca-se, a partir deste diálogo, compreender o período pós-colonial brasileiro, focado nas continuidades que persistem, assim como nas violências e segregações de nossa sociedade, na qual a principal afetada pelas mortes é a juventude masculina, entre os 15 e 29 anos, predominantemente negra e moradora das periferias de São Paulo e pelo Brasil, de onde saíram os integrantes do grupo.

Palavras-chave: Facção Central; antirracismo; anticolonialidade.

Abstract:The purpose of this article is to analyse the representations contained in the álbum $A$ marcha fúnebre prossegue, of the paulista rap group Faç̧ão Central in debate with anticolonials and antiracists thinkers like Achille Mbembe and Frantz Fanon, as well as their thoughts about coloniality and one way to produce one revolution in the realities that affect the black and poor people. It is sought, from this dialogue, understand the brazilian post-colonial period, focused in persisting continuities, as well as our society's violences and segregations, in which the main affected is the male youth, between 15 and 29 years old, predominantly black and resident of the suburbs of the São Paulo and around the Brazil, where they came.

Keywords: Facção Central; antiracism; anticoloniality.

\footnotetext{
* Mestrando em História Cultural pela Universidade de Brasília.
} 
Fundado em 1989 na capital paulista, na Praça da Aclimação, ${ }^{1}$ o Facção Central, hoje composto apenas pelo rapper Dum Dum, é um dos mais conhecidos grupos de rap de São Paulo e do Brasil, cuja produção alcança os 8 álbuns e centenas de músicas. Formado na maior parte dos álbuns pelo trio Erick 12 (produtor), Eduardo Taddeo (intérprete/compositor) e Dum Dum (intérprete), as músicas deste grupo se mostram como possibilidades de repensar as continuidades e marcas da colonização ainda vivas no país mesmo após quase dois séculos de sua formal independência política. Entre as quais, a própria quantidade de violências ao qual as pessoas habitantes dos bolsões de pobreza no país passam diariamente e os instrumentos de segregação econômica, espacial e racial utilizados pelos setores da sociedade que detém a maioria de pessoas na elaboração das políticas estatais. Seria a colonialidade restrita ao passado ou estaria ela na matriz do próprio presente?

A partir de tais epistemologias, o presente artigo tem por intuito estabelecer um diálogo entre o grupo de rap $^{2}$ analisado e os pensadores que refletem sobre o racismo e a colonialidade, com enfoque em Achille Mbembe e Frantz Fanon, cujas obras abordam os desafios provenientes de reflexões sobre os grilhões que ainda persistem nas nações colonizadas. Os autores, tais como os rappers do Facção Central, buscam refletir sobre narrativas que tratam das reações dos cidadãos excluídos, tentando também encontrar probabilidades e caminhos que possam levar estes povos a uma revolução social, política, cultural e econômica, muito embora as concepções deste termo entre eles nem sempre se aproximem.

A interdisciplinaridade pode ser enriquecedora para a historiografia. Estudar e reconhecer tais persistências, sob pontos de vistas diferentes no tempo e no espaço se impõe como um mecanismo ímpar a fim de se unir teoria e prática. Neste quesito, o Facção Central compõe suas músicas dentro da contemporaneidade recente, abarcando

\footnotetext{
${ }^{1}$ Esta narrativa é contada pelo rapper Mag (ex-Nego), que se coloca como fundador do Facção Central, em 1989. Para mais detalhes, ver o vídeo A história do Facção Central (Documentário Rap). Disponível em: https://www.youtube.com/watch?v=fo6yVL2JLBY\&t=458s. Acessado em: 12/03/2017.

${ }^{2}$ Existem dicionários que adotaram a palavra rap em português. De acordo com o Dicionário Priberam da Língua Portuguesa, rap significa o estilo de música popular que serve de suporte ao débito de palavras em rima, improvisadas ou não, marcadas num ritmo muito sincopado. "in Dicionário Priberam da Língua Portuguesa [em linha], 2008-2013, Disponível em: https://www.priberam.pt/dlpo/rap.
} 
aqui o estudo das memórias e representações contidas nos raps da denominada Aquarela pós-colonial - esta que será falada ao longo do texto. Portanto, a análise de discurso e a história do tempo presente são importantes para a pesquisa, pois não pode se perder de vista que os poderes e representações presentes nas músicas dialogam com outros eventos desta época de produção, como é o caso do álbum $A$ marcha fúnebre prossegue.

\title{
"Acredito na palavra ou na metralhadora, revolução verbal ou aterrorizadora": alguns debates antirracistas e anticoloniais.
}

\author{
A igualdade social é só em conto de fadas. \\ Felicidade só em sonho, só em mágica. \\ Acredito na palavra ou na metralhadora, \\ Revolução verbal ou aterrorizadora. \\ Vamos queimar constituição com coquetel molotov, \\ Carro-bomba no Congresso, tic-tac, explode! \\ Súplica pro gambé derrubando a sua porta, \\ Não bater na sua mulher, não atirar nas suas costas. ${ }^{3}$
}

No ano de 2001, o grupo de rap Facção Central lançou o álbum A marcha fúnebre prossegue, composto de representações e memórias dos rappers a respeito do genocídio da juventude masculina de São Paulo e do Brasil, entendida entre os 14 e 29 anos, cuja maioria era composta por pobres e negros. Entende-se por memória a perspectiva de Maurice Halbwachs, na qual esta reminiscência, mesmo que individual, não pode ser entendida fora da coletividade e de seus processos significativos (Cf. HALBWACHS, 1990: 22).

Acerca do genocídio, este nome foi dado pela primeira vez por Raphael Lemkim, no livro Axis rule in occupied Europe: laws of occupation, analysis of government, proposal for redress, aplicando este significado ao extermínio judaico, este evento que foi muito citado em analogia à situação dos pobres e negros no Brasil pelo Facção Central no álbum Direto do campo de extermínio, lançado em 2002 e também no álbum de 2001, como na própria música citada acima, onde há um verso que diz:

Até quando comer resto, lavar banheiro,

Abrir o boy no meio na ilusão de dinheiro?

\footnotetext{
${ }^{3}$ Retirada da música Discurso ou revólver, presente no álbum A marcha fúnebre prossegue. 
Ser exterminado como judeus em Auschwitz, Mostrar pra Globo o que é viver no limite?

A cruz da Klan queimando na sua frente, A SS agora veste o cinza da PM De braço cruzado é só miolo espalhado no chão Discurso ou revólver, tá na hora da revolução!

Para Abdias Nascimento, a definição de genocídio não se limita ao extermínio físico de um grupo, mas abarca também a destruição simbólica do mesmo (Cf. NASCIMENTO, 1978: 8). Entretanto, para efeito deste trabalho, serão predominantemente ressaltas as violências físicas narradas pelo grupo estudado. Inferese que os autores fazem perguntas ao interlocutor, as relacionando num contexto de tempo e espaço. Quando acabará a pobreza, a busca pelo dinheiro por meio da violência? Até quando tais pessoas teriam de mostrar, em vida, como sobreviver no limite?

Neste ínterim, os autores fazem uma comparação com o programa No Limite, exibido pela Rede Globo entre os anos 2000 e 2002, com retomada em 2009, onde os participantes ficavam confinados em florestas, passando por complexos testes de resistência física e psicológica. Na visão dos rappers, todos esses testes vividos pelos participantes do programa não se comparam com a situação de uma pessoa da periferia que tem de sustentar uma casa por meio de um salário-mínimo ou menos, correndo o risco de perder a vida a qualquer instante, massacrado diretamente ou indiretamente - essa por meio das condições estabelecidas no locus onde vivem - pelas forças que controlam o Estado.

Até quando as periferias serão assassinadas em massa, tais como ocorreram com os judeus nos campos de concentração, vide o exemplo de Auschwitz? Há de ser ressaltado, embora não colocado na letra, que outros segmentos eram tidos como inferiores e/ou perigosos pelo regime nazista, tais como negros, gêmeos, ciganos, padres, homossexuais, comunistas, anarquistas, portadores de deficiências físicas e/ou mentais. Genocídio que, em sua versão brasileira, afeta majoritariamente a juventude formada em grande parte por negros e pobres nos mais variados rincões.

Não à toa que no verso seguinte, os rappers fazem referência à cruz queimando, símbolo da Klu Klux Klan - nome de uma série de movimentos que, entre outas pautas, reivindicavam o predomínio da supremacia branca pelo uso da intimidação e violência a

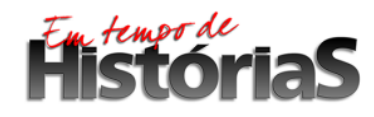


fim de atingir seus objetivos. Esta cruz não queimaria apenas nos Estados Unidos, mas também no Brasil. Neste ínterim, estaria presente, também em tom metafórico, a Schutzstaffel (SS), tropa paramilitar criada para a proteção dos ideais e personalidades ligadas ao Partido Nazista, também responsáveis pelos genocídios durante o regime hitlerista. A versão desta SS seria metamorfoseada na cor cinza que vestem os policiais militares no Brasil, que os rappers acusam de serem decisivos para o genocídio destes povos.

Sendo este o primeiro álbum depois da censura orquestrada pelo Ministério Público de São Paulo ao clipe da música Isso aqui é uma guerra, ${ }^{4}$ as críticas ao Estado e à liberdade de expressão são correntes. Percebe-se que a primeira faixa deste álbum é marcada por diversos recortes de noticiários que citavam o Facção Central como apologistas do crime. Neste ínterim, a análise de discurso nos é muito cara. Eni Orlandi afirma que o discurso não pode ser entendido apenas como pertencente a uma língua em um sistema abstrato, mas como um processo em curso que busca significar e entender algo, cujas palavras chegam a nós repletos de significados (Cf. ORLANDI, 1999: 32). Dentro deste discurso existem relações de poder entre sujeitos afetados pela linguagem, pensamento e pela história, tais quais os rappers, seus ouvintes e os sujeitos aos quais eles se referem nas músicas.

Como o foco será dado às músicas rap do já citado grupo, a relação entre história e música, área de interesse que anda crescendo em suas publicações acadêmicas, também é fulcral a pesquisa. Neste ínterim, as informações contidas nas músicas também ilustram acontecimentos e eventos cotidianos de um lugar (Cf. MANOEL, 2014: 4). Esta informação em muito dialoga com a perspectiva do historiador Marcos Napolitano, na qual o pensamento em torno das músicas populares - muito embora o autor questione os limites entre erudito e popular - nos mostram que são processos em que existem circularidades, mas também lutas (Cf. NAPOLITANO, 2002: 48-49), o que não faz com que a relação entre a história e música seja intrinsecamente dependente entre uma e outra.

\footnotetext{
${ }^{4}$ No ano 2000, o grupo de rap Facção Central sofreu com a censura de seu videoclipe Isso aqui é uma guerra pelo Ministério Público de São Paulo, acusado de apologia ao crime. Não à toa que os rappers foram se defender no programa da Sônia Abraão, na RedeTV!, e no programa do João Gordo, exibido na MTV, ambos no mesmo ano. Para melhor apreensão do conteúdo por parte do leitor, sugiro assistir ao clipe, disponível em: https://www.youtube.com/watch?v=dXbpOiEHQhA.
}

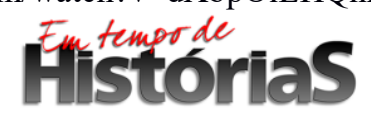


Por falar em atualidade, este é o panorama temporal onde as músicas do grupo e os demais acontecimentos se desdobram. Consoante Jean Santos, a história do tempo presente tem o mesmo valor que a historiografia do século XIX e de outros séculos, pois nenhuma está imune de preconceitos e erros por parte dos historiadores (Cf. SANTOS, 2009: 10-11), o que abre espaço para novas fontes, como os depoimentos orais. Acerca da história oral, os fundadores desta metodologia, tais como James Mink e Louis Starr, entendem que depoimentos pessoais, desde que interpretados, podem dar um grande enriquecimento à historiografia (Cf. GRELE, 2005: 77) a partir da compreensão sobre seres humanos não abarcados por outras correntes de pensamento historiográfico. O rap do grupo almeja construir representações a respeito da realidade que vivem e refletem, buscando apresentar essas representações ao ouvinte na dramaticidade que sentiram.

$\mathrm{Na}$ esteira da discussão a respeito da história do tempo presente, ao fazer uma reflexão sobre a lei e ordem nos governos FHC (1995-2002), Sérgio Adorno aponta eventos violentos de repercussão nacional que ocorreram durante seu segundo mandato, como as rebeliões na Fundação Estadual para o Bem Estar do Menor (FEBEM-SP), em 2000, tais como as ações do Primeiro Comando da Capital (Cf. ADORNO, 2003:12), ambas ocorridas em São Paulo. O autor liga estes ocorridos ao crescimento exorbitante do número de assassinatos no período. Percebe-se que este contexto do qual o grupo falava ainda tem muitas continuidades. Para maiores efeitos explicativos, é mister fazer uma exposição dos dados contidos nos livros do Mapa da violência de 2004. Segundo este livro, o número de homicídios registrados no Estado de São Paulo em 2001 foi de 15.745 pessoas (Cf. WAISELFISZ, 2004: 31).

Dados obtidos da Secretaria de Administração Penitenciária de São Paulo apontam que, em dezembro de 2001 haviam 67.649 encarcerados no estado de São Paulo (Cf. NADANOVSKY, 2009: 3), próximo aos 67.624 presos contabilizados em dezembro de 2001 e disponibilizados pelo website da Secretaria da Administração Penitenciária (SAP), ${ }^{5}$ vinculada ao governo de São Paulo, o que demonstra como as prisões passavam a ficar cada vez mais abarrotadas ao passo que havia uma redução no número de assassinatos comparados aos anos anteriores. Esta informação se choca com os dados

\footnotetext{
${ }^{5}$ Disponível em: https:/www.sap.sp.gov.br/noticias/not147.html. 
obtidos no Mapa da violência de 2004. No ano 2000 o montante de assassinatos era de 15.631, enquanto no outro ano subiu para os já citados 15.745 pessoas (Cf. WAISELFISZ, 2004: 31). É neste emaranhado de acontecimentos que o Facção Central trará as inspirações para suas músicas.

Na faixa Sem luz no fim do túnel, lançada no álbum A marcha fúnebre prossegue, de 2001, busca narrar essas mesclas de desesperanças e lamentos com um instrumental a dialogar com os gêneros Soul e Rhythm \& Blues, inclusive com suaves sons de guitarra e saxofone acompanhada às batidas compassadas. Em uma parte da música, os rappers explanam:

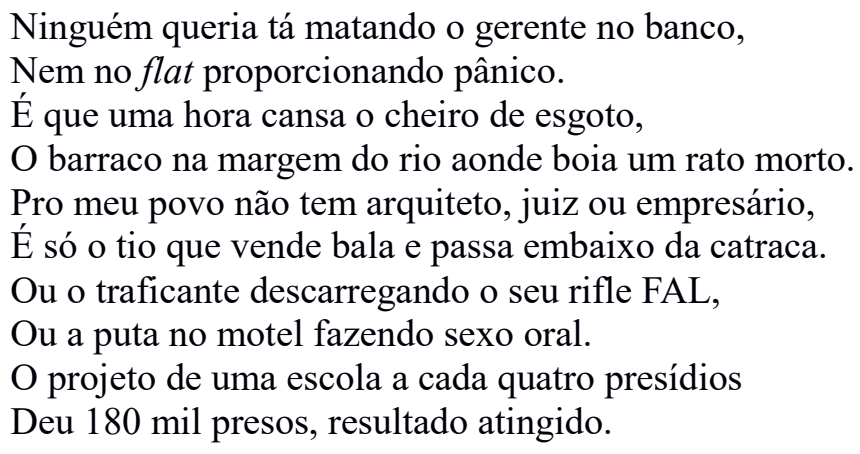

Percebe-se que estes utilizam o luto e a dor no embasamento às suas narrativas. Num território onde as violências, segregações e falta de oportunidades são latentes, cidadãs e cidadãos das periferias são influenciadas(os) a virarem prostitutas, moradores de rua, traficantes, vendedoras e vendedores de doces, refrigerantes e água nos sinaleiros, tais como assaltantes de banco. Infere-se que no primeiro verso citado, os rappers fazem relação ao cotidiano e a uma cena existente no citado clipe da música Isso aqui é uma guerra, quando um dos assaltantes descarrega sua pistola na cabeça do gerente em pleno assalto a um banco.

Vale lembrar que muitas das faixas do álbum estudado no presente artigo confrontam as ideias que levaram à censura do clipe por meio de ironias ou ataques diretos. Muitas destas pessoas acabam presas, tendo ou não infringido as leis explícitas no Código Penal. O encarceramento em massa, na opinião dos rappers, se sustenta na visão de que é mais prático para os governantes construírem presídios a fim de isolar as legiões de seres marginalizados em vez de agir contra as estruturas que garantem a

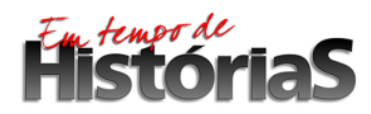

(PPGHIS/UnB) №. 32, Brasília, Jan - Jul 2018 ISSN 2316-1191 
reprodução de tais desigualdades, pois estas ajudariam a garantir seus privilégios. Este montante de vidas perdidas e trancafiadas, em números que mais se parecem com um país em plena guerra civil, não pode ser entendido fora das permanências advindas dos períodos coloniais.

Vivendo um mundo recém-liberto do poder político exercido pelo Reino Unido sobre o que seria a República de Gana, Kwame Nkrumah $^{6}$ definiu que pouca coisa havia mudado naquele curto espaço de tempo, pois as nações africanas viviam em um modelo político de balcanização, sendo este um termo cunhado por socialistas alemães do século XIX referente aos pequenos países balcânicos antes da Primeira Guerra Mundial, onde predominavam os conflitos étnicos e a dependência das potências à época, (Cf. MIR, 2004: p.42) cujo "barril de pólvora" está pronto para explodir a qualquer momento. Neste processo, o que conta é dividir para conquistar. A balcanização é relativamente análoga ao que acontecem nas periferias brasileiras. Este barril de pólvora não está pra explodir, mas explode todos os dias, cujo atos mais graves se dão na imensa quantidade de homicídios, encarceramentos, segregações econômicas, raciais e espaciais.

Como dito anteriormente, esta violência abrange vários ramos. Barulhos de tiros e gritos que ressoam na mente em forma de trauma, a lembrança da mãe pedindo esmola no sinaleiro, do pai alcoólatra que batia nos filhos ou mesmo a ausência perene deste pai, as agressões à esposa, o vício do filho em drogas, a não recusa da filha em vender seu corpo como objeto sexual para sobreviver, as memórias do desemprego e subemprego, o convívio diário com um meio em que, muitas vezes, os únicos que possuem maior poder aquisitivo são traficantes de armas, drogas, contrabandeio de produtos, bem como estelionatários e alguns assaltantes. Esses traumas frequentemente narrados nas músicas do Facção Central estimulam possíveis retaliações contra sua sorte. Tais episódios têm semelhanças com algo que ocorreu e ainda ocorre nas nações africanas.

Ao fazer uma reflexão a respeito do imaginário do colonizado - relacionando aqui linguagem e pensamento - Frantz Fanon escreve que os norte-africanos - se referindo aos argelinos - são despidos do direito à humanidade pela colonização, seja na afetividade, atividades sociais, em seus direitos, tornando-se uma espécie de morto em vida (Cf.

\footnotetext{
${ }^{6}$ Nkrumah. apud SANCHES, 2011: 287-288. 
FANON, 1980: 17), olhado com nojo e munido do ódio pela sua pessoa, por suas origens étnico-raciais e por onde vive, semelhante, mas com suas devidas particularidades, à realidade do Brasil, um país que foi colonizado mais de três séculos pelas forças lusitanas e que ainda hoje respira os ares deste período histórico.

É verdade que ele era um entusiasta pelo caminho da violência a fim de se destruir a sociedade colonial por completo, buscando com que esse negro pudesse se "libertar do arsenal de complexos germinados no seio da situação colonial” (FANON, 2008:44). Caminho este que é bastante pensado pelo Facção Central na já citada música Discurso ou revólver, muito embora a indecisão entre a "palavra" e o "revólver" seja latente nos versos. Escrevendo durante o fervor revolucionário argelino (Cf. FANON, 1980: 127), ele mostrou preocupação com a formação das novas nações africanas.

Muito embora não tenha vivido boa parte das independências, pôde perceber que países africanos descolonizados, como a Costa do Marfim, ainda estavam envolvidas numa espécie de pacto colonial, tanto econômico, como cultural. Nestes locais (Cf. FANON, 1980: 223) os serviços públicos não funcionam, seus operários vivem em condições análogas à escravidão e o povo, este que pegou em armas ou simplesmente alimentou a esperança de um novo horizonte, aqui se desiludiu em seu grande sonho. Sendo assim, até que ponto este e outros países africanos teriam se libertado de tais amarras?

Vivendo em um mundo "pós-colonial”, Achille Mbembe, tal qual Nkrumah, conseguiu refletir, em seu livro Sair da grande noite, com mais precisão acerca das inúmeras continuidades da colonização que o próprio Fanon, falecido em 1961. Tratando a descolonização como insurreição e experiência de emergência (Cf. MBEMBE, 2014: 19), embora descrente quanto aos rumos dos processos revolucionários africanos, concorda com Fanon de que o diálogo com o colonialista e a mudança de mundo por meio de suas estruturas é ineficaz.

Dentro de tal perspectiva existe a necessidade de uma sublevação armada para derrotar governos que se mantém eternos a partir das fraudes em urnas eleitorais, e mais ainda de valorizar a cultura e as línguas autóctones, tão fulcrais para sua autodefinição (Cf. COLLINS, 2016: 102-103). A despeito da ideia de violência, esta, por mais que tenha suas tolerâncias, não pode ser absoluta, pois corre no risco de ser prorrogada nos seus

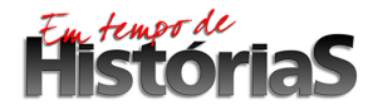

(PPGHIS/UnB) No. 32, Brasília, Jan - Jul 2018 ISSN 2316-1191 
mais diversos tentáculos, além de que essa praticamente só atinge o próprio africano e não os principais propagadores das condições estruturais e sistêmicas desta violência.

Os estudos de tais autores têm grande peso nos ajudar a compreender essas diferentes realidades do Brasil, na qual milhões de pessoas passam suas vidas sobrevivendo em meio às resinas deste passado que se presentifica. Infere-se que o próprio rapper Eduardo Taddeo sempre foi muito crítico quanto a estas continuidades (Cf. TADDEO, 2012: 100), na qual compara os grandes engenhos de açúcar com os atuais supermercados, e os aldeamentos de outrora com as catedrais luxuosas do presente. Em um artigo escrito para o jornal semanal sul-africano Mail \& Guardian, Achille Mbembe busca compreender o pesadelo de Fanon sobre possíveis desfechos trágicos para aquela que ele denominava de revolução africana (Cf. MBEMBE, 2004). Entre eles, há de ser ressaltado a ascensão de uma elite gananciosa e a formação de novos apartheids.

Neste ínterim, o Brasil, assim como as nações africanas descolonizadas, não se libertou dos tempos de América Portuguesa, entre as quais a deseducação, o patriarcalismo, o patrimonialismo, o messianismo, a dependência econômica por meio da exportação de commodities, o racismo, o extermínio de parcela da população e mesmo o ódio pelo seu semelhante. As periferias brasileiras são espaços vivos desta catastrófica herança, nas quais os direitos civis, sociais e políticos parecem não alcançar, pois são inúmeras as denúncias de violações aos mesmos em suas mais diversas instâncias.

A pobreza e demais mazelas nas comunidades, experiências vividas pelos rappers do grupo, são um "prato cheio" para alguém se tornar um criminoso, crescendo em locais sem infraestrutura, apoio governamental, educação, saúde, segurança, sem políticas públicas efetivas que buscam erradicar os problemas crônicos existentes. Dentro da faixa De encontro com a morte, o eu lírico descreve, em formato descontínuo num quesito temporal, algumas experiências de criança que agiram como traumas em sua mente, tendo papéis decisivos para que este mesmo ser humano entrasse na vida do crime.

Eu era só outro moleque jogando bola, Descalço, fazendo gol na porta da escola. Carente de incentivo, de um espelho. Hoje não tem aula, o professor não veio. Querendo brinquedo, carinho de alguém. Não paulada na cara do monitor da Febem.

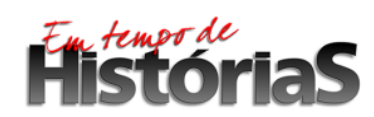


Não queria um rifle FAL aos 12 anos.

Eu não queria achar que o herói era o assaltante de banco.

Mas que cuzão que condena foi lá pra ensinar?

Aí moleque, a vitória só vem se estudar ou trabalhar.

Não é raro que essas cenas estejam presentes em tom de lamento em variadas músicas de rap no Brasil e do grupo estudada, como tentáculos do fenômeno colonialista. Aqui a raça e as condições de produção moldam as raízes que impedem o fim efetivo da colonização, mesmo quando as metrópoles já tenham perdido seu poder político institucional há centenas de anos (Cf. QUIJANO, 2002: 107). Cenas como desemprego, assassinatos, mendicância, subemprego, repressões policiais fazem parte da paisagem nestes espaços segregados em que a mixofobia (Cf. BAUMAN, 2005: 77-78), fobia em manter relações com a parte pobre das grandes cidades, é perceptível por parte dos setores da sociedade que controlam as instituições governamentais.

É neste espaço em que se dá o assassinato massivo de pessoas consideradas supérfluas para os grupos dominantes. No Brasil esta figura se apresenta naqueles refugiados em seu próprio país de origem, que sempre o renegou como ser humano e cidadão, buscando definir quando e quem deve morrer ou viver. Tal como diz o ex-rapper do Facção Central, Eduardo Taddeo, este processo de extermínio é reduzido, com apoio da mídia e das instituições públicas e governamentais a simples homicídios eventuais (Cf. TADDEO, 2012: 61). Ele não analisa as mortes destas pessoas como fatos isolados, mas no conjunto de vítimas para que demonstre que há não apenas omissão, mas que é o próprio Estado, controlado por uma pequena parcela da população, responsável por tais calamidades.

Dialogando com tal perspectiva, em seu livro Necropolítica, o filósofo Achille Mbembe atesta para a possibilidade da violência ser usada como um fim em si mesmo quando se trata de pessoas ligadas às estruturas estatais a fim de se manterem no poder (Cf. MBEMBE, 2011: 13-14). Assim a necropolítica seria uma espécie de involução da noção foucaultiana de biopoder, este segundo conceito que se refere às práticas do Estado moderno em regular os corpos, comportamentos e pensamentos das populações que habitam o espaço deste Estado. Dentro desta noção o poder político tem impacto direto sobre a vida dos cidadãos, decidindo quem merece morrer, pesando para estas decisões características como o fenótipo e as condições socioeconômicas. 
O Facção Central não está alheio destes eventos. A necropolítica é muito parecida com aquilo que o grupo denomina como Sistema brasileiro de $\operatorname{corpos}^{7}$, um nome que exalta em fortes tons a carnificina da qual, para ele, os principais culpados são as pessoas pertencentes às elites do país, apoderando-se do Estado e fazendo dali uma extensão de sua propriedade privada. Nota-se que o grupo não apenas lê estas estatísticas em noticiários, mas presenciou e presencia este genocídio desde quando eram crianças nos bairros periféricos na cidade de São Paulo, na forma de familiares, amigos e colegas que perderam suas vidas dentro desta temática que perpassa o álbum citado.

Em tempo, a discussão sobre representação é importante para a compreensão das músicas do Facção Central em diálogo com a produção acadêmica de autores póscoloniais, tais como Achille Mbembe e Frantz Fanon. Homi Bhabha localiza o discurso poético do colonizado, concebidos como representações, dentro do questionamento à memória hegemônica, bem como na propriedade em se autodefinir (Cf. BHABHA, 1998: 21). Infere-se nas músicas do grupo que eles não aceitam a imagem produzida pelo senso comum, ou, por vezes, a utilizam de maneira ressignificada ou figurada, tais quais as definições de "marginal", "bandido", "favelado", "preto" e "viciado".

Stuart Hall, por sua vez, concebe a representação como um essencial processo que é significado, produzido e compartilhado socialmente (Cf. HALL, 1997: 15). Tal qual uma representação ou mesmo como apresentação, estes são os modos pelos quais o grupo de rap vai trazendo as narrativas da vida na periferia. Quanto ao conteúdo destas representações contra-hegemônicas, existem variadas interpretações. Para Ecio Salles, a coletividade é fulcral ao militante, pois tudo que ele fala é tem como objetivo a comunidade, bem como de sua comunidade negra e pobre, cujo ouvinte constrói um texto ao entrar em contato com a música (Cf. SALLES, 2004: p.94).

Aproveitando estes dizeres, percebe-se que na já citada música Discurso ou revólver, contida neste $\mathrm{CD}$, os rappers - fazendo uso de um instrumental acelerado, barulhos de armas e explosivos, vozes desesperadas como se estivessem gritando, quebras nas escalas de seus refrões, cujo som é pronunciado não pela voz direta dos artistas, mas por um outro vocal grave, produzido em estúdio, cuja sonoridade leva o ouvinte ao

7 . A ideia de sistema brasileiro de corpos está presente em diversas músicas do grupo, entre as quais a faixa Brincando de marionetes, presente no álbum Estamos de luto, de 1998.

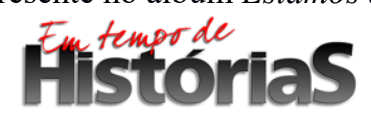


desespero permeante na música. Este beat foi sampleado a partir da música contida no filme infantil Mulan (1998), de produção da Disney, cujo nome é Transformation.

Nela eles denunciam os assassinatos e mostram as reações de quem vive nos bolsões de pobreza, tentam, em meio ao caos demonstrado pela própria estilística do rap, propor soluções entre o revólver - revolução por meio das armas - e o discurso entendido aqui como a revolução pelo meio das ideias. Entre os vários versos da música, dividida em estrofes, esta parte chama atenção para o já citado processo de necropolítica:

Fizeram da sua rua filial do Vietnã,

Deram rifle pras crianças, estupraram sua irmã.

Exilaram na favela o cidadão na teoria,

Oprimido e censurado no país da democracia.

Te dão crack, fuzil, cachaça no boteco,

Esse é o campo de concentração moderno.

Hitler, FHC, capitão-do-mato,

Bacharel de carnificina, mestrado em holocausto.

Este período do rap, cantado por Eduardo Taddeo, representa, seleciona, sistematiza e narra detalhes daquela que este mesmo rapper chama em seu livro de guerra não declarada, não raro que passe de uma situação particular para se chegar a um contexto geral. Partidas de diversas memórias pessoais e impessoais, depreende-se que a situação presenciada pela população periférica não é muito distante de países onde as guerras causaram severos estragos, como é o caso da comparação de uma rua na periferia, não especificado de onde seria o lugar, com o Vietnã, país que mesmo após a guerra, continuou a viver décadas sob o escombro dos conflitos.

Estupros, pilhagens, armas nas mãos de crianças, pobreza, assassinatos perpetrados diretamente ou indiretamente - por meio das condições socioeconômicas gestadas - são termos fortes, utilizados para dar uma imagem destes espaços segregados onde a dor parece não ter fim. Mesmo que sejam considerados cidadãos pela Constituição Federal de 1988, seus direitos civis pouco são efetivados na prática, vivendo exilados nas favelas, espaços em que o Poder Público intervém, na maioria das vezes, para reprimir seus moradores.

\section{Fitistorias}


Não à toa que os rappers citam Fernando Henrique Cardoso em comparação com Adolf Hitler e os capitães do mato, ${ }^{8}$ pois, para eles, o presidente é um dos principais culpados deste genocídio. Ironicamente, eles utilizam as expressões "bacharel" e "mestrado" para se aludir às titulações que o ex-presidente ganhou em sua vida acadêmica, mas num contexto não usual, pois em vez de invocarem os cursos de formação, citaram as atrocidades que era qualificado para fazer. Esses mesmos responsáveis aos olhos dos rappers não estariam imunes das reações por parte do povo preto e periférico. Esta temática é bem parecida com aquilo que os mesmos artistas relatam na música Justiça com as próprias mãos, do mesmo álbum:

Eu tô aqui defendendo o interesse da favela,

Que quer teu sangue pra preencher o vazio da panela.

Vim fazer vingança, buscar indenização

Pro seu crime hediondo, justiça com as próprias mãos.

Está aberta a sessão, começa o julgamento,

Tenho provas contundentes pro seu sepultamento.

Oitão na cabeça, fica quieta, vadia!

Transformou o moleque do pipa num sanguinário homicida.

Aqui se vê que os rappers reassumem seu compromisso de serem defensores dos interesses da favela, como espécie de porta-vozes das periferias ou, como dito pelo próprio grupo, "locutores do inferno". ${ }^{9}$ No próximo verso percebe-se que o interesse da favela é de matar essas pessoas acusadas de roubarem suas oportunidades. Seria o interesse dos próprios artistas ajudarem nessas violências físicas? Logo após eles citam, em primeira pessoa, que vieram fazer vingança, o que se segue no decorrer da música, aludindo os significantes às cenas de um tribunal de guerra que decreta penas capitais aos acusados, próximo do cotidiano nas ruas, nas cenas de assalto, latrocínios e sequestros.

Percebe-se que no primeiro verso citado, os rappers fazem alusão ao cotidiano e à cena citada em Isso aqui é uma guerra, quando um dos assaltantes descarrega sua pistola na cabeça do gerente em pleno assalto a um banco. Vale lembrar que muitas das faixas do álbum estudado no presente artigo confrontam as ideias que levaram à censura do clipe

\footnotetext{
${ }^{8}$ Capitão do mato era a pessoa designada, nos tempos coloniais, para vigiar e recuperar os escravizados revoltados ou fugidos dos senhorios e fazendas. Por vezes estes eram pessoas com descendência indígena ou africana, o que levou muitos rappers brasileiros fazerem essa associação à polícia do país, bem como àqueles que traem os populares para se engrandecer sobre seus escombros.

${ }^{9}$ Contida na música Versos sangrentos, do álbum de mesmo nome, lançado em 1999.
}

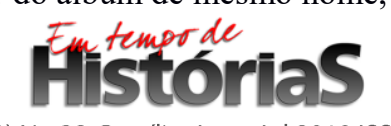


por meio de ironias ou ataques diretos. Não obstante, o verbo "vir", conjugado na primeira pessoa no singular, aponta para um sujeito escondido da oração.

No contexto da música, este pode se remeter ao povo rebelado, muito embora quando o grupo utilize tais formas verbais, algumas pessoas, ao fazerem a leitura, podem interpretar como apologia ao crime. Acontece que, assim como outros grupos de rap, o Facção Central busca narrar os sentimentos e raivas das pessoas que habitam os bolsões de pobreza, transmitindo suas emoções e ações, por vezes violentas, para reagir às tamanhas violências sofridas.

Na última parte a vítima é uma mulher, representada pelo adjetivo desqualificativo - e sexista - de "vadia". Longe de se esquivar do machismo presente em letras deste grupo ou de vários outros grupos de rap no Brasil e fora dele, percebe-se que este discurso mira predominantemente àquelas pertencentes às classes ricas, também consideradas culpadas pelo genocídio existente no país. Logo, o ser que habita as favelas não apenas é um ser que apanha e é morto, mas também é um ser que, indignado, reage violentamente contra os seus pares e contra aqueles cidadãos das elites e classes médias que vê como culpados pelo seu destino. Nascidos no meio deste estado de exceção, têm suas vidas regadas neste campo de concentração com drogas - representadas na música pelo crack e álcool, armas, pobreza e humilhação, está pronto e motivado para tentar virar um novo "rei do crime" em vez de acatar passivamente as rédeas que as condições socioeconômicas e culturais lhes impõem. Ao final da estrofe, mais uma comparação com o período colonial brasileiro, aqui não entendido como um passado inatingível, mas como o próprio Reinhart Koselleck denomina de espaço de experiência, local em que diversas noções de presente e passado se entrecruzam (Cf. KOSELLECK, 2006: 306-307).

O senhor do engenho usando farda e pistola para "descarregar na cabeça de um pobre" dentro do navio negreiro - analogia ao próprio Brasil como uma grande senzala é uma metáfora que alude a uma ligação apontada por aqueles versos em que comparam FHC, o capitão do mato e Hitler, ambos agindo em perspectivas parecidas a fim de perpetrar seu poder e exterminar aqueles que, para eles, devem ser mortos. É bem forte a presença das continuidades advindas dos tempos coloniais nesta música, pois as reações, tal como trabalham Fanon e Mbembe, não podem ser compreendidas longe das violências sofridas.

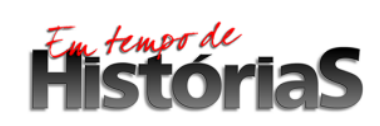


A música $A$ marcha fúnebre prossegue também se insere dentro desta perspectiva, cujo beat foi produzido em inspiração à música $I$ hear voices, do grupo de soul e $R \& B$ The Dells. Beat este que traz ao ouvinte uma sensação de tristeza, enquanto que no refrão, após uma quebra marcada por uma flauta, volta à mesma melodia, onde os rappers inserem o canto falado, em dicção forte e acelerada algumas partes, o que pode levar o ouvinte a enfatizar tais partes na música, esta de caráter pessimista ao trazer as memórias que permeiam o cotidiano da periferia paulista.

Tá rindo quer dançar? Quer se divertir?

Meu relato é sanguinário, playboy não vai curtir.

Sou homem pra falar que o moleque do pipa,

Esquecido que um dia troca tiro com a polícia.

Não simulo sentimento pra vender CD,

Não vou falar de paz vendo a vítima morrer.

Vendo no DP, o mano cumprindo pena,

Matando o seguro pra ter transferência.

Desta maneira, não há como o eu lírico narrar aquilo que ele não vive. Se ele recebe violência, se ele está praticando violência, como a apresentada - vendo sua vítima ser assassinada - é muito difícil para ela cantar fantasias de uma vida bela. Percebe-se que esta parte também é escrita de modo a chocar o interlocutor, na maneira que os próprios rappers se colocam no lugar daquele morador que está assaltando e, muito embora tenham desacreditado da vida do crime como instrumento para conseguir ascensão social, conviveram a vida toda nas comunidades e sabem que o pensamento de muitos, tomados pelo ódio, são parecidos com este.

Aqui há de se fazer um intertexto com a música do mesmo álbum denominada $O$ show começa agora, em que os $m c$ 's fazem críticas ao apoio recebido por pagodeiros e artistas sertanejos pela mídia, enquanto que o rap, principalmente o considerado "som pesado", é sistematicamente excluído.

Pagodeiro, sertanejo vem vender CD

A campanha do burguês tem cobertura da TV

Dá pra se promover e até pagar de santo

Fingir que meu filho morre, cuzão que rebola tá se importando.

\section{Filistorias}

(PPGHIS/UnB) №. 32, Brasília, Jan - Jul 2018 ISSN 2316-1191 
Infere-se que os rappers se incomodam com o fato dos apresentadores e artistas de programas de entretenimento na TV, que tanto buscam plantar alegria nos rostos dos telespectadores, são os mesmos que não se importarão com seu filho, ao contrário do rap, música que pode salvar vidas. Dentro da citada música Discurso ou revólver, depreendese que seu refrão tende a dar uma outra perspectiva à juventude periférica, procurando mostrar que o caminho da violência não levarão estas pessoas ao estrelato, pois, como fala o próprio Eduardo Taddeo, é muito raro alguém conseguir ascensão pela criminalidade sem ter nascido em "berço de ouro".

Tá na hora de parar de mofar no presídio, De estar no necrotério com uma pá de tiro, De ser o analfabeto comendo resto, Viciado que o DENARC manda pro inferno.

Os rappers se distanciam, em certa medida, da perspectiva fanoniana em pegar as armas e usar a violência como suporte para conseguir dias melhores. É verdade que a violência tratada de Fanon está ligada a um movimento de proporções materiais e humanas bem mais amplos, de revoluções independentistas propriamente ditas, enquanto que o contexto vivido pelos rappers é marcado pela revolta dos cidadãos despossuídos.

Malgrado que não se passa aqui uma perspectiva de tomar o Estado, mas de pessoas que buscam um meio de conseguir dinheiro, não tardando em produzir reações violentas contra a sociedade que sempre os rejeitou e, de maneira mais direta, contra as camadas privilegiadas e protegidas pelo confinamento em condomínios, carros blindados, latarias contra o efeito de tiros, seguranças particulares, bem como uma maior proteção por parte das forças policiais.

Este complexo de violências é muito mais combatido pelo Estado de Direito quando praticada por um cidadão despossuído e/ou negro. Neste ínterim, está na hora de procurar a revolução, mas não pela vingança, da criminalidade, do tráfico, pois as consequências legais ou extralegais costumam ser bem mais duras quando se tratam de cidadãos despossuídos. Pouco vale matar o "playboy” se um tempo depois o algoz "mofará" por vários anos no presídio ou morto. Buscar a criminalidade urbana como solução, dentro da concepção do grupo, é fazer o que o "sistema quer", da forma que não ameaçará as estruturas reinantes, além de auxiliar para que a perseguição e número de

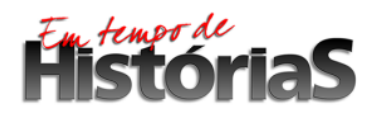

(PPGHIS/UnB) №. 32, Brasília, Jan - Jul 2018 ISSN 2316-1191 
mortos, encarcerados, inválidos por lesões físicas aumente mais, dando o motivo fático para que órgãos e instituições policiais, governamentais possam agir com repressão a fim de manter seus privilégios na sociedade.

Os rappers do Facção Central, dentro da faixa Sei que os porcos querem meu caixão, fazem referência à maneira como conseguiram sair das amarras, se esquivando da criminalidade e das alternativas que levariam estes mesmos seres humanos às ruínas.

\author{
O Brasil não aceita pobre revolucionário, \\ O marginalizado defensor do favelado. \\ Fugi do controle, quebrei a algema, \\ Expandi meu veneno, meu ódio, minha crença. \\ Contaminei o povo, revolta incurável, \\ Terrorista verbal, discurso implacável.
}

Neste ínterim, o país não acata a ideia de ver uma pessoa que sofra das mazelas econômicas que, além de sair da posição social desfavorável, busque ajudar a implantar a autoestima e senso crítico naqueles que são de origem semelhante para que não aceitem seus destinos como naturalmente determinados, tanto que assim se portam como "defensores do favelado". Estariam estes buscando o protagonismo na luta pela memória e ação nas periferias ou se portando como pessoas que buscavam mudanças, mas expressando o papel de agência de cidadãs e cidadãos periféricos?

Estes rappers buscaram "quebrar as algemas" que prendiam essas vozes de se expressarem e espalharam seus dizeres, assim "contaminando" o povo, mais precisamente a parcela periférica e negra. Por conta da acidez dos discursos e por falarem em temas que são tabus sociais, seriam tachados de "terroristas verbais", cujo discurso é implacável contra as moléstias contemporâneas. Tais moléstias ainda carregam marcas do período colonial, não à toa que Taddeo denomina um dos capítulos de seu livro como "Aquarela Pós-Colonial", quando, pouco depois, vai rebater o nome, dizendo que ainda somos colonizados, não pelo império português, mas como núcleo de extração estadunidense e dos países da Europa (Cf. TADDEO, 2012: 147).

Mas como se daria este processo tão delicado, visto que os meios para o cidadão periférico sair desta situação análoga às mazelas vividas pelos escravizados nos tempos coloniais são escassos? Nesta mesma música, mais especificamente na quarta parte, o eu

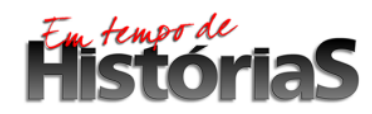


lírico aponta para duas possíveis saídas que viabilizariam esta revolução para os cidadãos despossuídos:

Caminho um: a voz do povo aqui não é a voz de Deus.

Se tua casa é de caixote de feira, problema seu.

Tanto faz sua filha no motel ganhando trocado,

Tanto faz seu filho com a 12 matando vigia no asfalto.

Se vier pro asfalto fazer passeata,

Aí o PM te mata, te faz engolir bandeira e faixa.

Caminho dois: desconhecendo o cenário político,

Onde jogar granada? Quem é o nosso inimigo?

Entendeu por que não tem escola pra você?

Toma a Uzi e me diz quem tem que morrer.

Não adianta ser milhões se não somos um,

Ação coletiva, objetivo comum.

Discurso ou revólver, não interessa a opção.

Sem união é impossível a revolução.

Aqui se faz mais uma vez o diálogo anticolonial que se adentra nas discussões também levantadas por Fanon e Mbembe. Neste primeiro caminho, existe a situação do individualismo, na qual os $m c$ 's fazem crítica: a voz do povo, da sociedade, que não reflete a voz de Deus. Pouco importa se o filho de um despossuído está matando alguém pelas mais diversas motivações ou se a filha está na prostituição de modo a ajudar no sustento da família, pois o que valeria é apenas a ascensão pessoal, sem pensar no bem coletivo das próprias pessoas que moram junto na comunidade ou com as quais sempre conviveu. E, caso a pessoa insatisfeita resolva manifestar contra sua sorte ou a de sua comunidade, será reprimida e/ou morta pela Polícia Militar.

O caminho dois demonstra uma situação distinta: de alguém que tem energia e ódio para fazer uma revolta violenta, por meio das granadas e metralhadoras Uzi, mas não sabe distinguir quem é o inimigo. Para muitas destas pessoas, o principal produtor de seus infortúnios é a pessoa mais próxima, muitas vezes convivendo na mesma habitação ou em um estrato social, econômico e racial idêntico ou semelhante, com quem se digladia no dia a dia, o que Taddeo questiona com veemência, comparando estes episódios com o de Ruanda, na qual a população - mesma raça, mesmo idioma, condições econômicas análogas - se mata entre si (Cf. TADDEO, 2012: 63).

O que possibilitaria a revolução social tão esperada, bem como o rompimento com este referido passado, parecidos com os citados pesadelos de Fanon. Seria o presente,

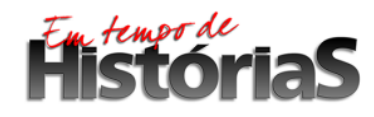


neste caso, uma espécie de passado? Os rappers, por sua vez, tocam muito na função da educação a fim de possibilitar transformações mais sólidas. Um exemplo disto se dá na faixa Apologia ao Crime, na qual o beat progressivo e acelerado é marcado, entre outros instrumentos, por guitarra, sintetizador e caixas de ritmos, enquanto que Eduardo Taddeo e Dum Dum buscam dar o flow ${ }^{10}$ acelerado, fulcral ao prosseguimento da música.

Ao longo de toda a canção, o eu lírico aponta para o crime em uma perspectiva de armadilha calculada e muito bem utilizada pelas classes possuídas para trucidar sem pena os despossuídos que descumprem a legislação vigente ao ingressar na criminalidade. Vale ressaltar que este título é utilizado de maneira irônica, ainda se referindo à acusação que levou o Ministério Público de São Paulo a censurar o grupo.

Pega a. 380 e faz a planta do banco.

Atira no segurança, chuta o refém que tá chorando.

Cata o malote, esvazia o cofre,

Descarrega na cabeça do gerente sua Nove [Pistola de calibre 9 milímetros].

Ou põe a roupa de carteiro pra enganar o porteiro,

Enquadrar o prédio inteiro, roubar jóia, dinheiro,

Pra 6 horas eu te ver no Cidade Alerta,

Algemado, com hematomas, tipo um cachorro numa cela.

O sistema tem que chorar, mas não com você matando na rua,

$\mathrm{O}$ sistema tem que chorar vendo a sua formatura.

Infere-se que o cidadão que pega uma arma, atira no segurança, descarrega o pente de uma pistola de calibre $9 \mathrm{~mm}$ na cabeça de um gerente bancário ou tenta roubar moradores de um condomínio ao se passar por carteiro só terá um destino ao fim do dia: ser preso e exibido pelas imagens televisivas em um programa sensacionalista de jornalismo policial, este que fará a total cobertura da detenção para o país.

Neste caso, e os rappers se aproximam de uma visão defendida nas obras de Fanon e Mbembe, sobre a importância de buscar conceber sua cultura e realidade, as raízes dos males que lhes afligem, expressos na significação desta palavra "formatura". Em vez de fazer as pessoas causadoras dos males chorarem pela potência dos calibres, este choro será proporcionado pelo potencial libertador da educação, deixando de fazer o que o "sistema" quer que seja feito.

10 . Dentro da cultura hip-hop, o termo flow se refere ao fluxo, à levada que o rapper (ou $m c$ ) consegue dar à seu canto falado enquanto que é tocado o beat.

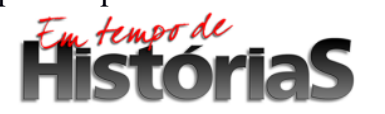




\section{Conclusão}

Portanto, o diálogo realizado entre o grupo de rap Facção Central e os pensadores pós-coloniais, como o caso de Achille Mbembe e Frantz Fanon, se mostra como uma possibilidade para buscar compreender a abrangência destes estudos a fim de apreender aspectos que influenciam o cotidiano das populações periféricas, cujas principais vítimas fatais são jovens de 15 a 29 anos predominantemente negros, estas que os rappers sempre buscaram lutar contra o esquecimento de suas memórias e pela melhoria das condições nas periferias, bem como construir meios para que estas buscassem sua valorização, inclusive através de diversos projetos sociais e palestras.

Esta não se daria por meio de práticas violentas, visto pelos $m c$ 's do grupo como um caminho ilusório, mas por outros meios, como: do trabalho, educação e mesmo o ativismo social, a militância, de forma que estes mesmos cidadãos parem para refletir sobre suas vidas e sobre as várias continuidades que permeiam o cotidiano "pós-colonial" no Brasil. Não são raras as referências do grupo ao período colonial de modo a se referir como se este passado estivesse bem ali, inteiro e vivo, pela presença metamorfoseada de seus diversos atores.

A pessoa que almeja fazer acontecer a tão sonhada revolução não pode desprezar este presentificado passado, pois incorrerá no erro de manter as compreensões de outrora, enquanto que a juventude preta e pobre, dentro das condições gestadas neste locus, continua a se matar por conta de um ponto de drogas, traição, desconfiança, falta de dinheiro, dívida com traficantes ou mesmo quando as forças estatais ajudam a manter essas populações no berço do desemprego, da deseducação e da fome, aliadas às forças policiais que, comandadas pelo Estado, utilizam meios legais e extrajudiciais para arrancar a vida destes cidadãos.

\section{Referências Bibliográficas}

\section{Fontes}


A história do Facção Central (Documentário Rap). Disponivel em: https://www.youtube.com/watch?v=fo6yVL2JLBY\&t=458s

CENTRAL, Facção. Versos Sangrentos. São Paulo: Discoll Box, 1999. 1 compact disc (ca.1h e 13 min). CENTRAL, Facção. A marcha fúnebre prossegue. São Paulo: EUO Entertainment, 2001. 1 compact disc (ca. $1 \mathrm{H}$ e $11 \mathrm{~min}$ ).

\section{Bibliografia}

ADORNO, S. Lei e ordem no segundo governo FHC. Tempo social, São Paulo, v.15, n.2, nov.2003. Disponível em: http://www.scielo.br/scielo.php?script=sci_arttext\&pid=S0103-20702003000200005. Acesso em: 12/10/2018.

BAUMAN, Zygmunt. Confiança e medo na cidade. Rio de Janeiro: Jorge Zahar, 2009.

BHABHA, Homi. O local da cultura. Belo Horizonte: Editora UFMG, 2013.

COLLINS, Patricia Hill. Aprendendo com a outsider within: a significação sociológica do pensamento feminista negro. Socidade \& Estado, Brasília, vol.31, n.1, pp.99-127, jan-abr. 2016.

GRELE, Ronald J. The view from where we stand: oral history and expanded horizons. História Oral, Rio de Janeiro, v. 8, n. 2, p. 77-85, jul.-dez. 2005.

FANON, Frantz. Em defesa da revolução africana. Lisboa: Sá da Costa, 1980.

FANON, Frantz. Pele negra, máscaras brancas. Salvador: Edufba, 2008.

HALL, Stuart et.al. Representation: cultural representations and signifying practices. Milton Keynes: Open University, 1997.

HALBWACHS, Maurice. A memória coletiva. São Paulo: Revista dos Tribunais, 1990.

KOSELLECK, Reinhart. Futuro Passado: Contribuição à semântica dos tempos históricos. Rio de Janeiro: Contraponto, Ed. PUC-Rio, 2006.

MANOEL, D. S. Música para historiadores: [re]pensando canção popular como documento e fonte histórica. In: Encontro Regional de História. Profissão Historiador: Formação e Mercado de Trabalho. 19., 2014, Juiz de Fora. Anais... Juiz de Fora: ANPUH, 2014. p. 1-10.

MBEMBE, Achille. Fanon's nightmare, our reality. 2011 - Disponível em: http://mg.co.za/article/201112-23-fanons-nightmare-our-reality/. Acesso em: 21/11/2017.

MBEMBE, Achille Necropolítica / Sobre el gobierno privado indirecto. Editorial Melusina, Santa Cruz de Tenerife, 2011.

MBEMBE, Achille. Sair da grande noite: ensaios sobre a África descolonizada. Luanda: Mulemba, 2014.

MIR, Luis. Guerra civil: Estado e trauma. São Paulo: Geração Editorial, 2004.

NADANOVSKY, P. O aumento no encarceramento e a redução nos homicídios em São Paulo, Brasil, entre 1996 e 2005. Caderno de Saúde Pública, Rio de Janeiro, 25(8): 1859-1864, ago/2009.

NAPOLITANO, Marcos. História \& Música. Belo Horizonte: Autêntica, 2002.

NASCIMENTO, Abdias. O genocídio do negro brasileiro: processo de um racismo mascarado. Rio de Janeiro: Paz e Terra, 1978.

ORLANDI, Eni Puccinelli. Análise de discurso: princípios \& procedimentos. 8. ed. Campinas: Pontes, 2009.

QUIJANO, Aníbal. Colonialidade, poder, globalização e democracia. Novos rumos, n.37, p.4-28, 2002.

SALLES, E. A narrativa insurgente do hip-hop. Estudos de Literatura Brasileira Contemporânea, Brasília, v.1, n. 24., p. 89-109, jul-dez. 2004.

SANCHES, Manuela Ribeiro. Textos anti-coloniais, contextos pós-coloniais. Lisboa: Edições 70, 2011.

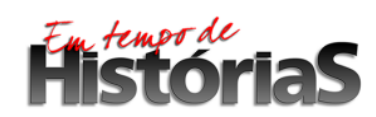

(PPGHIS/UnB) №. 32, Brasília, Jan - Jul 2018 ISSN 2316-1191 
SANTOS, J.M.C.T. Atualidade da história no tempo presente. Revista Historiar, Rio de Janeiro, v.1, n.1, p.7-13, 2009.

TADDEO, Carlos Eduardo. A guerra não declarada na visão de um favelado. São Paulo: Edição do autor, 2012.

WAISELFISZ, Jacob. Mapa da violência IV Os jovens do Brasil: juventude, violência e cidadania. Brasília: UNESCO, 2004.

WAISELFISZ, Jacob. Mapa da violência 2016: homicídios por arma de fogo no Brasil. Brasília: UNESCO, 2016. 